\title{
Altered Renin Release and Propranolol Potentiation of Vasodilatory Drug Hypotension
}

\author{
William A. Pettinger and Kent Keeton \\ From the University of Texas Southwestern Medical School, Departments of \\ Pharmacology and Internal Medicine, Dallas, Texas 75235
}

A в STRACT Vasodilating antihypertensive drugs induce hypotension with reflex tachycardia, renin release, and fluid and electrolyte retention. Propranolol can impair this renin release. The studies described here were designed to determine the hemodynamic role of vasodilatory drug-induced renin release and inhibition thereof by propranolol in two animals models, the unanesthetized, normotensive and the unanesthetized, genetically hypertensive rat. In studies with normotensive rats, propranolol impaired renin release and tachycardia resulting from hydralazine and minoxidil and potentiated their hypotensive action. Two additional interventions against the renin-angiotensin system were used in evaluating the mechanism of this potentiation. One was removal of the renin source by nephrectomy, and the second was blockade of angiotensin's vasoconstrictor action using a selective angiotensin antagonist, saralasin (1Sar-8-Ala-angiotensin II [previously known as P-113]). Both interventions potentiated vasodilatory drug hypotension, as did propranolol, but did not prevent reflex tachycardia. When combined with saralasin propranolol did not add to protentiation by this peptide. A similar pattern of blood pressure decrement and potentiation was seen in genetically hypertensive rats when propranolol or saralasin treatment preceded hydralazine. Propranolol was demonstrated to block hydralazineinduced increases in serum renin activity in genetically hypertensive rats. We conclude that hypotensive potentiation of vasodilating drugs by propranolol in these animal models is mediated to a large extent by impair-

This work was presented in part at the 30th Annual Meeting of the American Federation for Clinical Research, Atlantic City, N. J., April 1973. Part of the work described in this manuscript is in partial fulfillment of the requirements for the degree of Ph.D by Kent Keeton.

Dr. Pettinger is a Burroughs-Wellcome Scholar in Clinical Pharmacology.

Received for publication 3 August 1974 and in revised form 26 September 1974. ment of renin release. Persistence of hypotensive tachycardia after nephrectomy and after saralasin in normotensive rats suggests the irrelevance of angiotensin's central nervous system stimulation to this cardiac effect. Clinical studies are underway to quantify the potential importance of this beneficial drug interaction in man.

\section{INTRODUCTION}

When combined with propranolol, the vasodilatory drugs hydralazine and minoxidil yield an effective antihypertensive combination with few adverse effects (1-4). Vasodilatory drugs induce renin release both in man (5-7) and in animals (8), and a large portion of this renin release can be blocked by propranolol in animals (8). These studies were designed to determine if the increment in angiotensin formation resulting from an increase in serum renin activity limits vasodilatory drug hypotension, and, if so, does propranolol impairment of renin release contribute significantly to blood pressure lowering by the drug combination. After the administration of hydralazine or minoxidil, cardiovascular indices (heart rate and systolic blood pressure) were monitored in normotensive rats during three interventions: (a) propranolol impairment of renin release; $(b)$ removal of the renin source by prior nephrectomy, and (c) blockade of the vasoconstrictor action of angiotensin using a new, selective angiotensin antagonist, saralasin (1-Sar-8-Ala-angiotensin II). In addition mean arterial pressure was monitored in genetically hypertensive rats after treatment with propranolol, hydralazine, saralasin, propranolol plus hydralazine, and saralasin plus hydralazine.

\section{METHODS}

Normotensive, male Wistar (Simonsen Laboratories, Gilroy, Calif.) or genetically hypertensive (16-22 wk, Okamoto strain, Taconic Farms, Inc., Germantown, N. Y.) rats, weighing $180-250 \mathrm{~g}$, were housed individually and exposed 
TABLE I

The Blockade of Hydralazine-Induced Renin Release by Propranolol in the Genetically Hypertensive Rat

\begin{tabular}{lc}
\hline & $\operatorname{SRA}^{*}\left(\overline{\mathrm{X}}_{ \pm} \mathrm{SEM}\right)(n=7)$ \\
\hline $\begin{array}{l}\text { Saline control } \\
\text { Hydralazine } \\
(1.0 \mathrm{mg} / \mathrm{kg})\end{array}$ & $2.54 \pm 0.24$ \\
$\begin{array}{l}\text { Propranolol }+ \text { hydralazine } \\
(1.5 \mathrm{mg} / \mathrm{kg}) \quad(1.0 \mathrm{mg} / \mathrm{kg})\end{array}$ & $11.15 \pm 0.82$ \\
\end{tabular}

* SRA = nanograms $A_{I}$ per milliliter serum per hour at $37^{\circ} \mathrm{C}$.

to light by an automated system from 6 a.m. to 6 p.m. They ingested, ad lib., tap water and Purina rat chow (Ralston Purina Co., St. Louis, Mo.) containing $152 \mathrm{meq}$ of sodium $/ \mathrm{kg}$ of food.

Drug dosage and time of administration are given in the figure legends. Minoxidil (free base) and hydralazine $\mathrm{HCl}$ were injected intraperitoneally in normal saline. Propranolol $\mathrm{HCl}$ was injected subcutaneously to prolong its pharmacologic activity (8). Saralasin was solubilized in $0.1 \mathrm{M}$ Tris- $\mathrm{HCl}$ buffer, $\mathrm{pH} 7.5$ which contained $0.2 \%$ lysozyme, and mixed with four parts of Pharmagel A (in saline to give a final concentration of $15 \%$ ) immediately before subcutaneous injection. This method of administration assures potent pharmacologic activity for $60 \mathrm{~min}$ as gauged by the blockade of the pressor effects of intravenously administered angiotensin II to anesthetized, pentoliniumtreated rats. ${ }^{1}$

Systolic blood pressure of normotensive rats was recorded with an automatic tail cuff (Narco Bio-Systems, Inc., Houston, Tex.), pneumatic pulse transducer (Narco), and an electrosphygmograph coupler (Narco 7211) with a Narco DMP-48 physiograph. Heart rate was obtained from the tail pulse with this system. For comparable results in each figure, the same six animals were used in each experiment with 1-day washout periods interposed between each treatment with one exception; experiments in nephrectomized normotensive animals were done the day after surgery $(18 \mathrm{~h})$. Serum renin activity at this time was 0.1 $\mathrm{ng} / \mathrm{ml} / \mathrm{h}$ in six rats as compared to the normal control value of $2.5 \mathrm{ng}$ (see Table I).

The lack of effect of sham operation, in lieu of nephrectomy, was reported previously for similar hemodynamic studies involving anesthesia (9). Since the warming exposure necessary for the indirect measurement of blood pressure proved to be too stressful for the genetically hypertensive rats, direct mean arterial pressure was measured in genetically hypertensive rats using an indwelling Week's catheter placed in the descending aorta (10), a pressure transducer (Narco RP-1500), a strain gauge coupler (Narco 7172) and a Narco DMP-48 physiograph. The rats were used in hemodynamic experiments 5 days after surgery.

Biochemical experiments with genetically hypertensive rats (Table I) were performed with the same time sequences as with normotensive rats in Fig. 2. The technique

\footnotetext{
${ }^{1}$ Pettinger, W. A., K. Keeton, and K. Tanaka. 1974. The radioimmunoassay and pharmacokinetics of saralasin (1Sar-8-Ala-angiotensin II) in the rat and hypertensive man. Clin. Pharmacol. Ther. In press.
}

of blood collection from unanesthetized rats, the measurement of serum renin activity $(\mathrm{SRA})^{2}$ by radioimmunoassay, and the measurement of plasma propranolol levels, were as previously described (8). Statistical significance in the hemodynamic experiments was determined by using Student's $t$ test.

\section{RESULTS}

Biochemical studies with normotensive rats. Characteristics of vasodilatory drug-induced renin release and the effect of propranolol on this mechanism of renin release are summarized in Figs. 1 and 2. Fig. 1 gives the chronology of renin release by minoxidil and hydralazine as well as the log dose-response curve for the two drugs. Parts of these data were reported previously (8) and are extended and summarized here for ready comparison with hemodynamic events. The ability of different doses of propranolol to impair renin release caused by these two vasodilators are shown in Fig. 2. Here these data are not reported as actual SRA but rather as the percent inhibition by propranolol of increases in SRA from control values caused by the drugs

'Abbreviations used in this paper: MAP, mean arterial pressure SRA, serum renin activity.

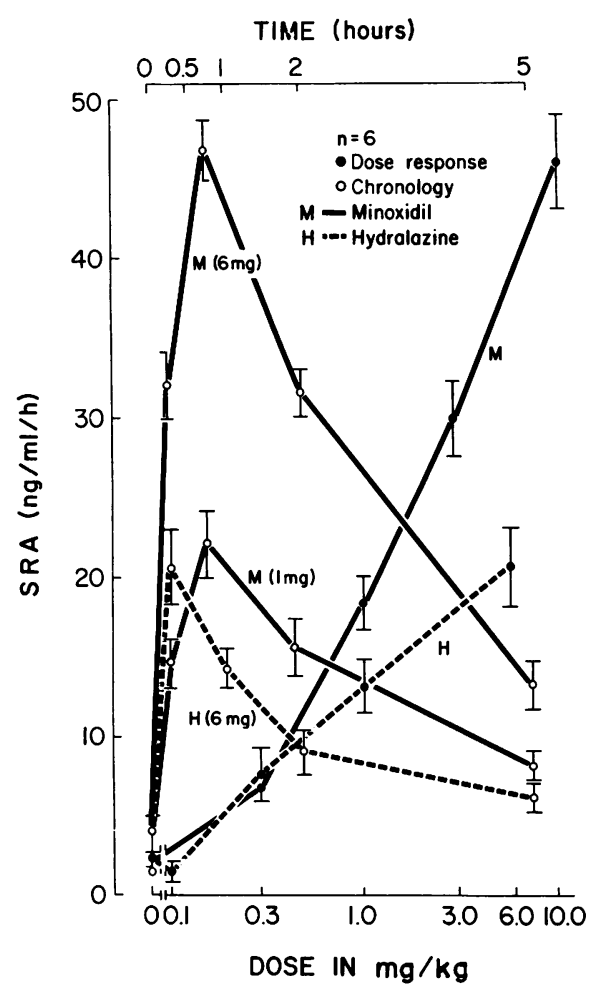

FIgURE 1 Dose response and chronology of hydralazine and minoxidil-induced renin release in normotensive rats. Blood for SRA was collected $20 \mathrm{~min}$ (hydralazine) and $40 \mathrm{~min}$ (minoxidil) after i.p. administration in the doseresponse experiments. Each value is the mean \pm SEM for six animals.

Renin and Vasodilatory Drug Hypotension 


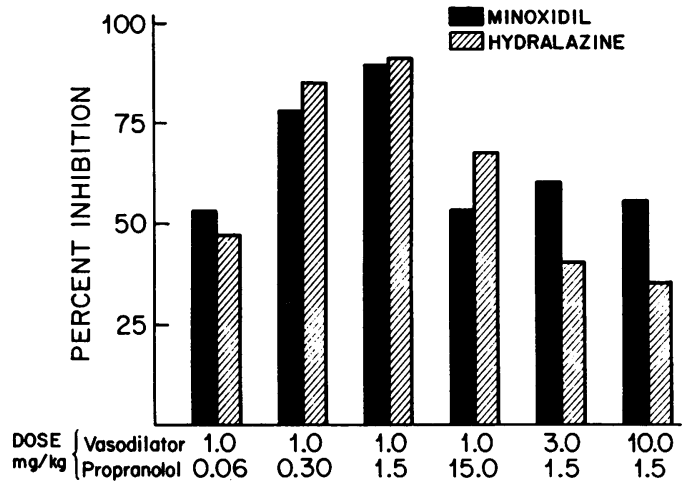

FIGURE 2 Impairment by propranolol of hydralazine- and minoxidil-induced renin release in normotensive rats. Propranolol was given s.c. $10 \mathrm{~min}$ before each vasodilator i.p. and blood collected $20 \mathrm{~min}$ after the hydralazine and 40 min after minoxidil treatment. (Each value is the mean for six animals).

minoxidil and hydralazine. Propranolol in a dose resulting in plasma levels below $20 \mathrm{ng} / \mathrm{ml}$, impaired $50 \%$ of minoxidil $(1.0 \mathrm{mg} / \mathrm{kg})$ - and hydralazine $(1.0 \mathrm{mg} / \mathrm{kg})$ induced renin release. 0.3 and $1.5 \mathrm{mg} / \mathrm{kg}$ propranolol gave plasma levels of $49 \pm 4$ and $222 \pm 19 \mathrm{ng} / \mathrm{ml}$, respectively (8) and gave maximal impairment of hydralazine- and minoxidil-induced renin release. A high dose of propranolol $(15.0 \mathrm{mg} / \mathrm{kg})$ giving plasma concentrations of $750 \pm 98 \mathrm{ng} / \mathrm{ml}$ resulted in less impairment of renin release than lower propranolol doses. Also higher $(3.0$ and $10 \mathrm{mg} / \mathrm{kg})$ minoxidil and hydralazine doses were capable of overriding propranolol's (1.5 $\mathrm{mg} / \mathrm{kg}$ ) inhibition of renal release.

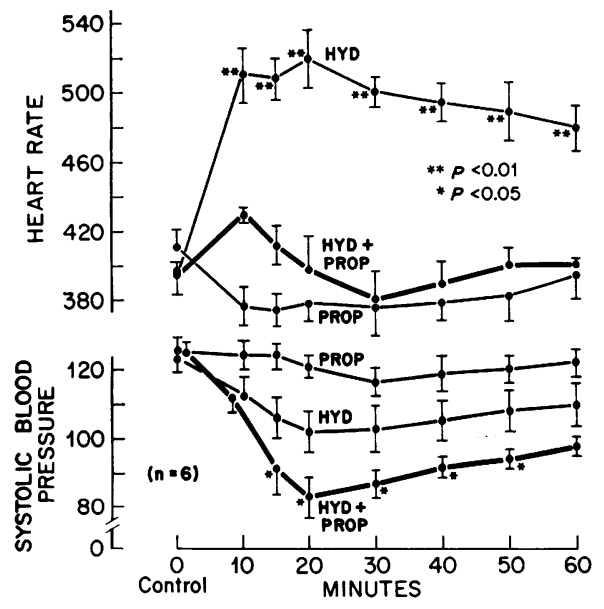

FIGURE 3 Hemodynamic changes following propranolol; hydralazine; and propranolol and hydralazine in normotensive rats. Propranolol $(1.5 \mathrm{mg} / \mathrm{kg})$ was given s.c. 10 min before hydralazine i.p. $(1.0 \mathrm{mg} / \mathrm{kg})$. Each value is the mean \pm SEM for six animals. Statistical tests are a comparison of the hydralazine treatment with the propranolol and hydralazine treatment.

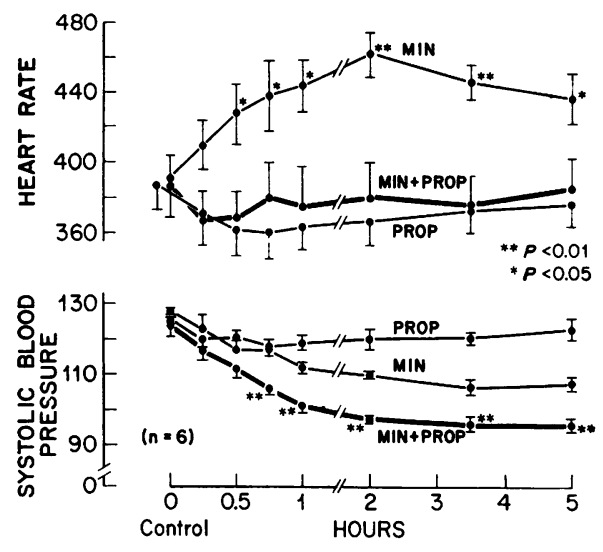

Figure 4 Hemodynamic changes following propranolol; minoxidil; and propranolol and minoxidil in normotensive rats. Propranolol $(1.5 \mathrm{mg} / \mathrm{kg})$ was given s.c. $10 \mathrm{~min}$ before minoxidil i.p. $(1.0 \mathrm{mg} / \mathrm{kg})$. Each value is the mean $\pm S E M$ for six animals. Statistical tests are a comparison of the minoxidil treatment with the propranolol and minoxidil treatment.

Hemodynamic studies with normotensive rats. $1 \mathrm{mg} /$ $\mathrm{kg}$ hydralazine (which results in a sevenfold increase in SRA) lowered average systolic blood pressure by $21 \%$ and markedly increased the heart rate (Fig. 3). In the same rats propranolol $(1.5 \mathrm{mg} / \mathrm{kg})$ lowered blood

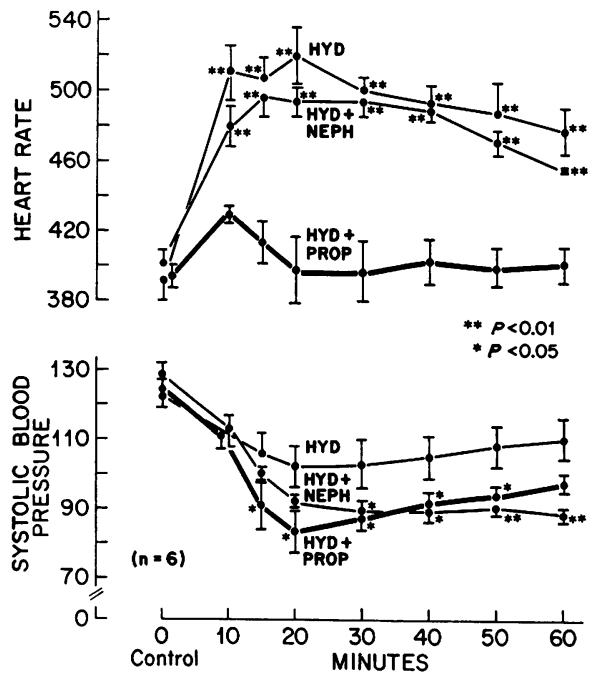

FIGURE 5 Hemodynamic changes following hydralazine; propranolol and hydralazine; and hydralazine after nephrectomy in normotensive rats. Propranolol $(1.5 \mathrm{mg} / \mathrm{kg})$ was given s.c. $10 \mathrm{~min}$ before hydralazine $(1.0 \mathrm{mg} / \mathrm{kg})$ i.p. The rats were nephrectomized $18 \mathrm{~h}$ before hydralazine (1.0 $\mathrm{mg} / \mathrm{kg}$ ) treatment. Each value is the mean \pm SEM for six animals. Statistical tests for blood pressure measurements are a comparison of hydralazine treatment with propranolol and hydralazine treatment or nephrectomy and hydralazine. Statistical comparisons for heart rate measurements are a comparison of propranolol and hydralazine treatment with hydralazine treatment or nephrectomy and hydralazine. 

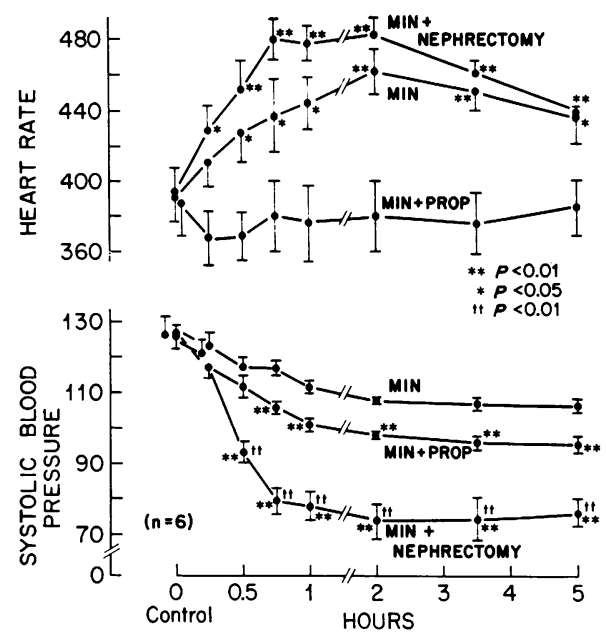

FIGURE 6 Hemodynamic changes following minoxidil; propranolol and minoxidil and minoxidil aíter nephrectomy (18 h previously) in normotensive rats. Propranolol (1.5 $\mathrm{mg} / \mathrm{kg}$ ) was given s.c. $10 \mathrm{~min}$ before minoxidil $(1.0 \mathrm{mg} /$ $\mathrm{kg}$ ) i.p. Each value is the mean \pm SEM for six animals. Statistical tests for blood pressure measurements (*) are a comparison of minoxidil treatment alone vs. propranolol and minoxidil or nephrectomy and minoxidil. Propranolol and minoxidil treatment is also compared $(\dagger \dagger)$ with nephrectomy and minoxidil. Statistical comparisons for heart rate measurements (**) are a comparison of propranolol and minoxidil treatment with minoxidil treatment or nephrectomy and minoxidil.

pressure by $5 \%$ and heart rate by $13 \%$. Combined treatment with propranolol and hydralazine lowered blood pressure by an average of $39 \%$ and mitigated the tachycardia caused by hydralazine alone.

Results of hemodynamic studies with the combination of minoxidil and propranolol (Fig. 4) are similar except for the prolonged duration of action with minoxidil. Propranolol and minoxidil reduced blood pressure by 3 and $15 \%$, respectively whereas propranolol decreased the heart rate and minoxidil, when given alone, markedly increased the heart rate. Again propranolol significantly $(P<0.05)$ potentiated minoxidil hypotension $(24 \%$ decrement in blood pressure) and prevented the associated tachycardia.

Removal of the source of renin by nephrectomy potentiated hydralazine- (Fig. 5) and particularly minoxidil- (Fig. 6) induced hypotension. However, nephrectomy did not alter the tachycardia caused by either vasodilator. The hydralazine hypotension after nephrectomy $(43 \%)$ was comparable to that with the combination of propranolol and hydralazine $(39 \%)$. Minoxidil $(41 \%)$ and hydralazine $(39 \%)$ hypotension after nephrectomy were comparable, but the blood pressure lowering with the minoxidil-propranolol combination $(24 \%)$ was only about one-half that of minoxidil and nephrectomy.

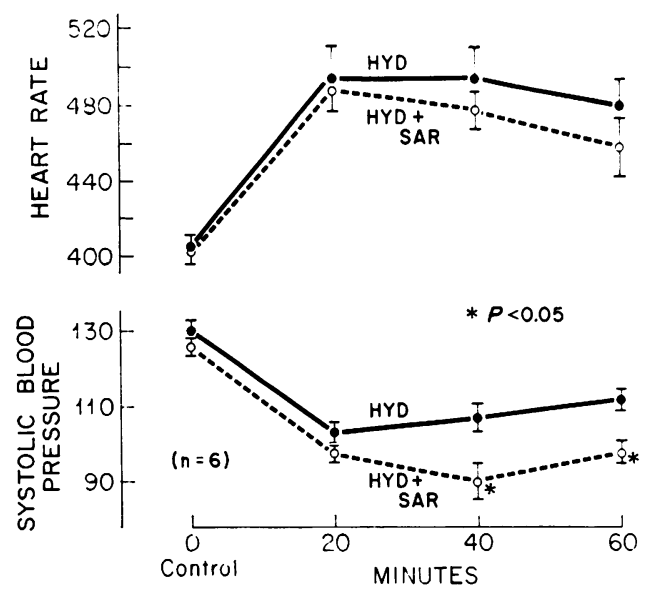

Figure 7 Saralasin potentiation of hydralazine hypotension in normotensive rats. Saralasin $(10 \mathrm{mg} / \mathrm{kg})$ was given s.c. $20 \mathrm{~min}$ before hydralazine $(1.0 \mathrm{mg} / \mathrm{kg})$ i.p. Each value is the mean \pm SEM for six animals.

Blockade of the vasoconstrictor effects of angiotensin with the selective angiotensin antagonist saralasin resulted in potentiation of hydralazine (Fig. 7) and minoxidil (Fig. 8) hypotension. Further studies were done in another group of rats to determine whether the effect of propranolol was additive to that of saralasin in potentiating hydralazine hypotension. The results in Fig. 9 show that saralasin $(10 \mathrm{mg} / \mathrm{kg})$ alone had no effect on blood pressure or heart rate. Again, hydralazine lowered blood pressure $(10 \%)$ with a concomitant increase in heart rate. This hypotension was potentiated with propranolol $(18 \%)$ which also blocked the tachycardia. Saralasin and hydralazine caused a greater decrease in blood pressure $(26 \%)$ than the propranolol-hydralazine combination, and the tachycardia pattern was similar to

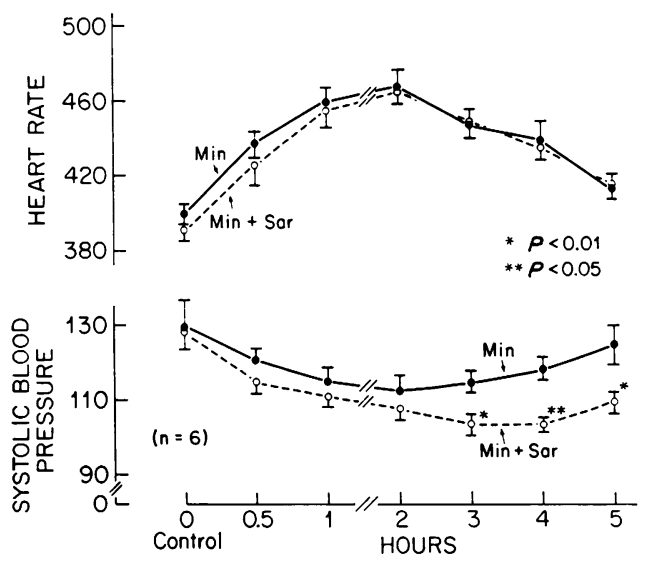

FIgURE 8 Saralasin potentiation of minoxidil hypotension in normotensive rats. Saralasin $(10 \mathrm{mg} / \mathrm{kg})$ was given s.c. $20 \mathrm{~min}$ before minoxidil $(1.0 \mathrm{mg} / \mathrm{kg})$ i.p. Each value is the mean $\pm S E M$ for six animals.

Renin and Vasodilatory Drug Hypotension 
that of hydralazine alone. Pretreatment with both saralasin and propranolol before hydralazine did not cause greater blood pressure lowering $(25 \%)$ than with saralasin pretreatment alone. The smaller percent decrease in blood pressure with hydralazine noted here compared with Fig. 3 appears to be due to biological variation between groups of rats as in patients. This is the reason that each rat was used as its own control in each group of experiments.

Biochemical studies with genetically hypertensive rats. The same pattern of blockade of hydralazine-induced renin release as seen in the normotensive rat (8) was observed in the genetically hypertensive rat ( $\mathrm{Ta}$ ble $\mathrm{I})$. Hydralazine $(1 \mathrm{mg} / \mathrm{kg})$ resulted in a fourfold increase in SRA, and propranolol pretreatment (1.5 $\mathrm{mg} / \mathrm{kg}$ ) blocked $95 \%$ of this increase.

Hemodynamic studies with genetically hypertensive rats. Results similar to those obtained with the normotensive (Fig. 9) rats were observed when the same drug combinations were administered to genetically hypertensive rats (Fig. 10). In the latter case, hydralazine $(1 \mathrm{mg} / \mathrm{kg})$ caused a $17 \%$ decrease in mean arterial pressure (MAP) whereas propranolol had an initial pressor effect $(10.2 \%)$ which was followed by a gradual decrease in blood pressure $(3.2 \%$ at $60 \mathrm{~min})$.

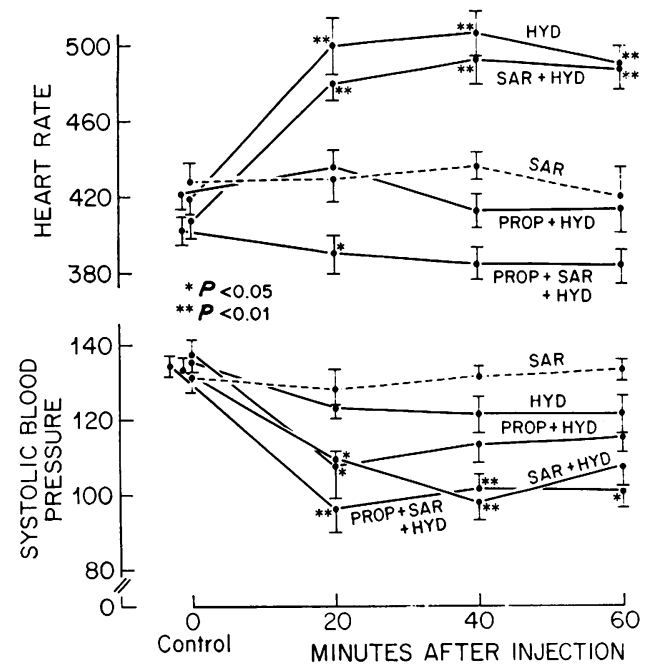

FIGURE 9 Hemodynamic changes hydralazine; saralasin; saralasin and hydralazine; propranolol and hydralazine; and saralasin, propranolol and hydralazine in normotensive rats. Propranolol $(1.5 \mathrm{mg} / \mathrm{kg})$ was given s.c. $10 \mathrm{~min}$ and $(10 \mathrm{mg} / \mathrm{kg}) 20 \mathrm{~min}$ before hydralazine $(1.0 \mathrm{mg} / \mathrm{kg})$ i.p. Statistical tests for blood pressure measurements are a comparison of hydralazine treatment with propranolol and hydralazine; saralasin and hydralazine; and propranolol, saralasin, and hydralazine treatments. Statistical tests for heart rate measurements are a comparison of propranolol and hydralazine treatment with hydralazine; saralasin and hydralazine; and propranolol, saralasin, and hydralazine treatments.

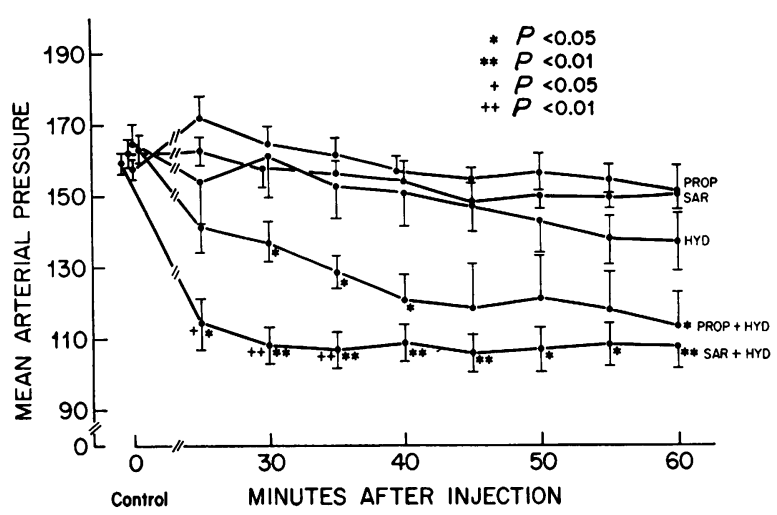

Figure 10 Hemodynamic changes following hydralazine; saralasin; saralasin and hydralazine; propranolol; and propranolol and hydralazine in genetically hypertensive rats. Propranolol $(1.0 \mathrm{mg} / \mathrm{kg})$ was given s.c. $10 \mathrm{~min}$ before hydralazine $(1.0 \mathrm{mg} / \mathrm{kg})$ i.p. Saralasin $(10 \mathrm{mg} / \mathrm{kg})$ was given s.c. $20 \mathrm{~min}$ before hydralazine $(1.0 \mathrm{mg} / \mathrm{kg})$ i.p. Statistical tests $\left(^{*}\right)$ are a comparison of hydralazine treatment with propranolol and hydralazine treatment or saralasin and hydralazine treatment. Propranolol and hydralazine treatment are also compared $\left(^{+}\right)$with saralasin and hydralazine treatment.

Saralasin alone $(10 \mathrm{mg} / \mathrm{kg})$ caused a significant decrement $(7.4 \%)$ in blood pressure at one time period (55 min). When the rats were pretreated with propranolol and then given hydralazine, propranolol significantly potentiated (28.9\% blood pressure decrease) the hypotension elicited by hydralazine. Saralasin pretreatment initially potentiated hydralazine hypotension more than propranolol, but after $35 \mathrm{~min}$ there was no significant difference between propranolol plus hydralazine $(28.9 \%)$ and salalasin plus hydralazine $(34.3 \%)$ despite the fact that the saralasin-hydralazine averages were less (approximately $10 \mathrm{~mm} \mathrm{Hg}$ ) than those of propranolol-hydralazine treatment.

Heart rate was not recorded during the different drug treatments since MAP was being measured in the genetically hypertensive rat.

\section{DISCUSSION}

Angiotensin has multiple sites of pharmacologic action including central nervous system-mediated cardiac stimulation (11-13), sympathetic neuronal activation (1417), and the well-known vascular and adrenal effects. Each of these pharmacologic actions contributes qualitatively to blood pressure elevation. The increment in SRA caused by vasodilating drugs significantly increases the levels of circulating angiotensin (18). This increment would be expected to antagonize or limit the hypotensive action of vasodilating drugs due to angiotensin's broad spectrum of activities as well as the dynamic relationship between angiotensin and vasodilators at the vascular smooth muscle sites of action (19). 
In these experiments with normotensive rats, impairment of renin release by propranolol was associated with marked potentiation of vasodilatory drug-induced hypotension. This observation is consistent with the hypothesis that increased angiotensin levels limit the effectiveness of systemic vasodilators, but it should be kept in mind that propranolol also blocks reflex cardiac stimulation. It has been suggested that the antihypertensive activity of propranolol alone may result from reduced cardiac output (20), but this mechanism of action has been criticized (21). Since we did not measure cardiac outputs in these experiments, the possibility that this potentiation by propranolol is due in part to its negative inotropic and chronotropic cardiac effects cannot be eliminated. Propranolol also may contribute by a central nervous system mechanism (22-24) to blood pressure reduction. Although propranolol accentuated the hypotension following both vasodilators, the potentiation due to hydralazine appeared to be more pronounced than that due to minoxidil. It is unknown whether this observation is related to chronologic differences in blood pressure depression and renin release by the two agents.

Removal of the renin source by prior bilateral nephrectomy resulted in marked potentiation of hydralazine- and minoxidil-induced hypotension. This remarkable potentiation is consistent with the idea that the increment in angiotensin formed from elevated SRA antagonized a major component of the hypotensive activity of the vasodilating drugs. Absence of urinary excretion of hydralazine (25), and minoxidil (26), however, could aslo contribute to this enhanced activity.

The marked tachycardia remaining after nephrectomy suggests that the cardiac stimulation precipitated by these vasodilating drugs is not dependent on angiotensinmediated central nervous system effects since the renin source is absent. This result also implies that blockade of the cardiac stimulation by propranolol is not the major potentiating mechanism of propranolol to the blood pressure decrement since this decrement occurred in presence of the tachycardia in nephrectomized animals.

Since propranolol can block both inotropic and chronotropic responses and since there is the possibility for error resulting from altered drug excretion following nephrectomy, our hypothesis was tested more specifically by using the selective angiotensin antagonist, saralasin (27). Saralasin potentiated hydralazine hypotension without altering the pattern of cardiac stimulation. Additionally, impairment of renin release with propranolol pretreatment did not induce blood pressurelowering greater than the pretreatment with saralasin. The greater efficacy of saralasin pretreatment is no doubt due to the fact that it is competitively blocking the smooth muscle receptor for angiotensin. Even though propranolol is quite efficient in blocking renin release with hydralazine $(91 \%$ at this propranolol dose, see reference 8 ), the small increment in angiotensin remaining may express some pharmacologic actvity. Thus, it is not surprising that a combined pretreatment with saralasin and propranolol could not potentiate hydralazine hypotension more than saralasin pretreatment alone.

Persistence of vasodilatory drug-induced tachycardia in nephrectomized and in saralasin-pretreated animals indicates that the cardiac stimulation is not dependent on central nervous system effects of angiotensin. A possible explanation is that saralasin did not have access to, or was ineffective in blocking an angiotensin receptor in the brain. However, this possibility seems unlikely since a peptide pharmacologically similar (1-Sar8-Ile-angiotensin II) to saralasin has previously been shown to block centrally mediated angiotensin stimulation in dogs (28) when angiotensin was administered from an exogenous source. In addition, studies of Pals and Fulton (29) provide evidence that the antihypertensive activity of saralasin in the acute phase of unilateral renal hypertension in rats was due in part to an antagonism of central nervous interactions of angiotensin II.

Brunner, Hedwall, and Meier (30) previously reported no potentiation of hydralazine hypotension in normotensive rats by propranolol. However, hydralazine was administered intravenously instead of intraperitoneally and the effect monitored for only $30 \mathrm{~min}$. Since a dynamic relationship exists between angiotensin and vasodilating drugs at the vascular smooth muscle site (19), the acute high plasma concentrations of hydralazine resulting from intravenous administration may have dominated angiotensin's effect to such an extent that no potentiation would be expected from propranolol during the brief interval of observation.

Qualitatively similar results were obtained in biochemical (Table I) and hemodynamic (Fig. 10) studies with genetically hypertensive rats. Propranolol, in a dose known to cause a 20 -fold displacement to the right of the isoproterenol (tachycardia) dose-response curve in normotensive rats (8), blocked $95 \%$ of the renin release elicited by hydralazine (Table $\mathrm{I}$ ) in the genetically hypertensive rat. In the normotensive rat, this dose of propranolol impaired $91 \%$ of the hydralazine-induced rise in SRA (8). Thus the impairment of vasodilatory drug-induced renin release is essentially the same in normotensive and genetically hypertensive rats.

If the results of the hemodynamic experiments with normotensive (Fig. 9) and genetically hypertensive (Fig. 10) rats are compared, a similar pattern of blood pressure decrement and potentiation was observed when propranolol or saralasin treatment preceded hydralazine.

Scriabine, Ludden, and Bohidar (31) recently re-

Renin and Vasodilatory Drug Hypotension 241 
ported potentiation of hydralazine hypotension using the beta adrenergic-blocking drug timolol, but failed to show similar potentiation by propranolol, in the genetically hypertensive rat. However, there were important technical differences from the studies reported here. Propranolol and hydralazine were administered orally in their studies. Both drugs are rapidly metabolized in the liver, particularly with the first dose or with low portal venous concentrations $(32,33)$. This technical difference could explain the variable presence of tachycardia in their hydralazine controls. In our experiments propranolol was administered subcutaneously, and effectiveness of the beta adrenergic blockade was confirmed along with measurements of propranolol blood levels (8). Also, we administered hydralazine parenterally and found rapid and consistent effects on blood pressure and heart rate. Alternatively, Scriabine, Ludden, and Bohidar (31) reported only the maximal blood pressure decrement noted during a $24-\mathrm{h}$ period. These technical differences may have resulted in their failure to demonstrate propranolol's potentiating effect.

A major side effect of treatment with antihypertensive vasodilators is reflex sympathetic stimulation resulting in increased heart rate and cardiac output (1-4). Propranolol was originally combined with vasodilators (it was known to possess some antihypertensive activity of its own $[22,34,35])$ to mitigate these untoward effects, but even greater benefit was gained from the combined drug treatment since the hypotensive efficacy of the vasodilator was increased (1). Bühler, Laragh, Baer, Vaughn, and Brunner's (36) recent evidence that suppression of renin release with propranolol correlated with the hypotensive effect of propranolol alone, is consistent with the thesis that potentiation of vasodilator drug hypotension by propranolol may operate via this mechanism.

\section{ACKNOWLEDGMENTS}

We are indebted to Dr. Castellion of Norwich Pharmacal for the saralasin $(P-113)$ and the gelatin formulation. The authors would like to thank Martha Williams for her technical assistance and Linda Moscatelli for her secretarial assistance.

This work was supported in part by the Texas Heart Association, Merck Foundation, and the Norwich Pharmacal Company.

\section{REFERENCES}

1. Gilmore, E., J. Weil, and C. Chidsey. 1970. Treatment of essential hypertension with a new vasodilator in combination with beta-adrenergic blockade. $N$. Engl. $J$. Med. 282: 521-527.

2. Zacest, R., E. Gilmore, and J. Koch-Weser. 1972. Treatment of essential hypertension with combined vasodilation and beta-adrenergic blockade. N. Engl. J. Med. 286: 617-622.

3. Aenishänslin, W., J. Pestalozzi-Kerpel, U. C. Dubach, P. R. Imhof, and M. Turri. 1972. Antihypertensive therapy with adrenergic beta-receptor blockers and vasodilators. Eur. J. Clin. Pharmacol. 4: 177-181.

4. Pettinger, W. A., and H. C. Mitchell. 1973. Minoxidil -an alternative to nephrectomy for refractory hypertension. N. Engl. J. Med. 289: 167-173.

5. Küchel, O., L. M. Fishman, G. W. Liddle, and A. Michelakis. 1967. Effect of diazoxide on plasma renin activity in hypertensive patients. Ann. Intern. Med. 67: 791-799.

6. Winer, N., D. S. Chokski, M. S. Yoon, and A. D. Freedman. 1969. Adrenergic receptor mediation of renin secretion. J. Clin. Endocrinol. Metab. 29: 1168-1175.

7. Ueda, H., Y. Kaneko, T. Takeda, T. Ikeda, and S. Yagi. 1970. Observations on the mechanism of renin release by hydrolazine in hypertensive patients. Circ. Res. Suppl. II. 27 : 201-206.

8. Pettinger, W. A., W. B. Campbell, and K. Keeton. 1973. Adrenergic component of renin release induced by vasodilating antihypertensive drugs in the rat. Circ. Res. 33: $82-86$

9. Tanaka, K., and W. A. Pettinger. 1974. Renin release and ketamine-induced cardiovascular stimulation in the rat. J. Pharmacol. Exp. Ther. 188: 229-233.

10. Weeks, J. R., and J. A. Jones. 1960. Routine direct measurement of arterial pressure in unanesthetized rats. Proc. Soc. Exp. Biol. Med. 104: 646-648.

11. Bickerton, R. K., and J. P. Buckley. 1961. Evidence for a central mechanism in angiotensin induced hypertension. Proc. Soc. Exp. Biol. Med. 106: 834-836.

12. Deuben, R. R., and J. P. Buckley. 1970. Identification of a central site of action of angiotensin II. J. Pharmacol. Exp. Ther. 175 : 139-146.

13. Joy, M. D., and R. D. Lowe. 1970. The site of cardiovascular action of angiotensin II in the brain. Clin. Sci. (Oxf.). $39:$ 327-336.

14. Keim, K. L., and E. B. Sigg. 1971. Activation of central sympathetic neurons by angiotensin II. Life Sci. 10: $565-574$.

15. Peach, M. J., W. H. Cline, and D. T. Watts. 1966. Release of adrenal catecholamines by angiotensin II. Circ. Res. 19 : 571-575.

16. Palaić, D., and P. A. Khairallah. 1967. Effect of angiotensin on uptake and release of norepinephrine by brain. Biochem. Pharmacol. 16: 2291-2298

17. Zimmerman, B. G., and J. Gisslen. 1968. Pattern of renal vasoconstriction and transmitter release during sympathetic stimulation in presence of angiotensin and cocaine. J. Pharmacol. Exp. Ther. 163: 320-329.

18. Blaine, E. H., J. O. Davis, and P. D. Harris. 1972. A steady-state control analysis of the renin angiotensinaldosterone system. Circ. Res. 30: 713-730.

19. Pettinger, W., H. Sheppard, Z. Palkoski, and E. Renyi. 1973. Angiotensin antagonism and antihypertensive activity of phosphodiesterase inhibiting agents. Life Sci. 12 : 49-62.

20. Frolich, E. D., R. C. Tarazi, H. P. Dustan, and I. H. Page. 1968. The paradox of beta-adrenergic blockade in hypertension. Circulation. 37: 417-423.

21. Prichard, B. N. C., and P. M. S. Gillam. 1969. Treatment of hypertension with propranolol. Br. Med. J. I: 7-16.

22. Ram, N., and H. C. Garvey. 1973. Comparative antihypertensive effects of beta-adrenergic blocking drugs. Fed. Proc. 32 : 724. (Abstr.)

23. Srivastava, R. K., V. K. Kulshrestha, N. Singh, and K. P. Bhargava. 1973. Central cardiovascular effects of 
intracerebroventricular propranolol. Eur. J. Pharmacol. 21: 222-229.

24. Stern, S., M. Hoffman, and K. Braun. 1971. Cardiovascular responses to carotid and vertebral artery infusions of propranolol. Cardiovasc. Res. 5: 425-430.

25. Zacest, R., and J. Koch-Weser. 1972. Relation of hydralazine plasma concentration to dosage and hypotensive action. Clin. Pharmacol. Ther. 13: 420-425.

26. Pluss, R. G., J. Orcutt, and C. A. Chidsey. 1972. Tissue distribution and hypotensive effects of minoxidil in normotensive rats. J. Lab. Clin. Med. 79: 639-647.

27. Pals, D. T., F. D. Masucci, G. S. Denning, Jr., F. Sipos, and D. C. Fessler. 1971. Role of the pressor action of angiotensin II in experimental hypertension. Circ. Res. 29: 673-681.

28. Sweet, C. S., C. M. Ferrario, M. C. Khosla, and F. M. Bumpus. 1973. Antagonism of peripheral and central effects of angiotensin II by [1-Sarcosine, 8-isoleucine] angiotensin II. J. Pharmacol. Exp. Ther. 185: 35-41.

29. Pals, D. T., and R. W. Fulton. 1973. Mechanism of the antihypertensive effect of 1-Sar-8-Ala-angiotensin II during acute phase of experimental renal hypertension. Arch. Int. Pharmacodyn. Ther. 204: 20-30.

30. Brunner, H., P. R. Hedwall, and M. Meier. 1967. In- fluence of adrenergic beta-receptor blockade on the acute cardiovascular effects of hydralazine. Br. J. Pharmacol. Chemother. 30: 123-133.

31. Scriabine, A., C. T. Ludden, and N. R. Bohidar. 1974. Potentiation of the antihypertensive action of hydralazine by timolol in spontaneously hypertensive rats. Proc. Soc. Exp. Biol. Med. 146: 509-512.

32. Shand, D. G., R. E. Rangno, and G. H. Evans. 1972. The disposition of propranolol. II. Hepatic elimination in the rat. Pharmacology (Basel). 8: 344-352.

33. McIsaac, W. M., and M. Kanda. 1964. The metabolism of 1-hydrazinophthalazine. J. Pharmacol. Exp. Ther. $143: 7-13$.

34. Majid, P. A., B. Sharma, C. Saxton, J. B. Stoker, and S. H. Taylor. 1970. Haemodynamic effects of oxprenolol in hypertensive patients. Postgrad. Med. J. Suppl. Nov. 67-72.

35. Werkö, L. 1971. New treatment for hypertension. Eur. J. Clin. Pharmacol. 3: 61-62.

36. Bühler, F. R., J. H. Laragh, L. Baer, E. D. Vaughn, Jr., and H. R. Brunner. 1972. Propranolol inhibition of renin secretion. a specific approach to diagnosis and treatment of renin-dependent hypertensive diseases. $N$ Engl. J. Med. 287: 1209-1214. 